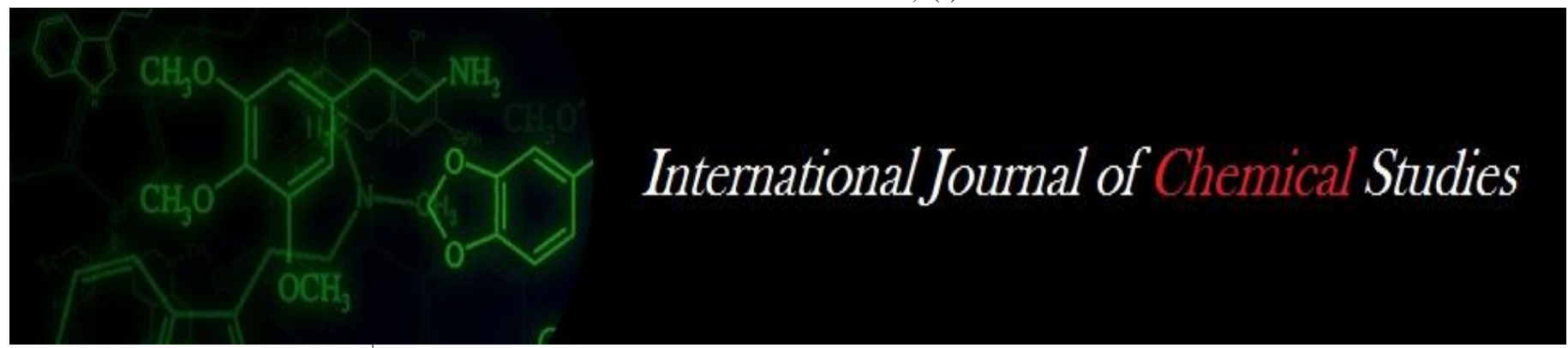

P-ISSN: 2349-8528

E-ISSN: 2321-4902

www.chemijournal.com

IJCS 2020; 8(2): 2856-2862

(C) 2020 IJCS

Received: 13-01-2020

Accepted: 15-02-2020

Vimal Singh Rajput

Department of Entomology,

College of Agriculture,

S.K.R.A.U., Bikaner, Rajasthan, India

Jayshree Jhala

Department of Entomology,

RARI, Durga Pura, Rajasthan,

India

VS Acharya

Department of Entomology,

College of Agriculture,

S.K.R.A.U., Bikaner, Rajasthan, India
Corresponding Author: Vimal Singh Rajput

Department of Entomology,

College of Agriculture,

S.K.R.A.U., Bikaner, Rajasthan,

India

\section{Biopesticides and their mode of action against insect pests: A review}

\author{
Vimal Singh Rajput, Jayshree Jhala and VS Acharya
}

DOI: https://doi.org/10.22271/chemi.2020.v8.i2ar.9184

\begin{abstract}
Biopesticides including entomopathogenic viruses, bacteria, fungi, nematodes, and plant secondary metabolites, are gaining increasing importance as they are alternatives to chemical pesticides and are a major component of many pest control programs. The virulence of various biopesticides such as nuclear polyhedrosis virus (NPV), bacteria, and plant product were tested under laboratory conditions very successfully and the selected ones were also evaluated under field conditions with major success. Biopesticide products (including beneficial insects) are now available commercially for the control of pest and diseases. The overall aim of biopesticide research is to make these biopesticide products available at farm level at an affordable price, and this would become a possible tool in the integrated pest management strategy. Moreover, biopesticide research is still going on and further research is needed in many aspects including bioformulation and areas such as commercialization. There has been a substantial renewal of commercial interest in biopesticides as demon- strated by the considerable number of agreements between pesticide com- panies and bioproduct companies which allow the development of effective biopesticides in the market. This paper has reviewed the important and basic defection of major biopesticides in the past. The future prospects for the development of new biopesticides are also discussed.
\end{abstract}

Keywords: Biopesticides, mode, action against insect pests

\section{Introduction}

\subsection{Biopesticides}

Biopesticides are developed from naturally occur- ring living organisms such as animals, plants, and microorganisms (e.g., bacteria, fungi, and viruses) that can control serious plantdamaging insect pests by their nontoxic eco-friendly mode of actions, therefore reaching importance all over the world. Biopesticides and their by-products are mainly utilized for the management of pests injurious to plants (Mazid et al. 2011) ${ }^{[44]}$.

Biopesticides are classified into three different categories: (1) plant-incorporated protectants, (2) microbial pesticides, and (3) biochemical pesticides. They do not have any residue problem, which is a matter of substantial concern for con- summers, specifically for edible fruits and vegetables. When they are used as a constituent of insect pest management, the efficacy of biopesticides can be equal to that of conventional pesticides, particularly for crops like fruits, vegetables, nuts, and flowers. By combining synthetic pesticide performance and environmental safety, biopesticides execute efficaciously with the tractability of minimum application limitations and with superior resistance management potential (Kumar 2012) ${ }^{[38]}$ Copping and Menn (2000) ${ }^{[15]}$ reported that biopesticides have been gaining attention and interest among those concerned with developing environmentally friendly and safe integrated crop management (ICM)-compatible approaches and tactics for pest management. In particular, farm- ers' adoption of biopesticides may follow the recent trend of "organically produced food" and the more effective introduction of "biologically based products" with a wide spectrum of biologi- cal activities against key target organisms, as well as the developing recognition that these agents can be utilized to replace synthetic chemical pes- ticides (Menn and Hall 1999; Copping and Menn 2000; Chandrasekaran et al. 2012) ${ }^{[46,15,12]}$. Insecticides from microorganisms extend a unique chance to developing countries to research, and they have possessed to develop natural biopesticide resources in protecting crops. The utilization of biopesticide programs would be required to prevent the development of resis- tance in target 
insect pests to synthetic chemical pesticides and toxins from biopesticides (Copping and Menn 2000; Senthil-Nathan 2006) $[15,62,65]$.

Compared with chemical pesticides, biopesti- cides do not present the same regulatory prob-

lems seen with chemical pesticides. Biopesticides are frequently target specific, are benign to beneficial insects, and do not cause air and water quality problems in the environment, and also agricultural crops can be reentered soon after treatment. Microorganisms from nature can also be used in organic production, and risks to human health are low. In addition, the usage of biopesti- cides has other several advantages; e.g., many target pests are not resistant to their effects (Goettel et al. 2001; EPA 2006) ${ }^{[27,21] .}$

Biopesticides derived from bacteria like Bacillus thuringiensis (Bt), a large array of fungi, viruses, protozoa, and some beneficial nematodes have been formulated for greenhouse, turf, field crop, orchard, and garden use (Hom 1996; Butt et al. 2001a, b; Grewal et al. 2005; EPA 2006) [33, 8, 31, 21]. Biocontrol microbials, their insecticidal meta- bolic products, and other pesticides based on living organisms are sorted as biopesticides by the EPA. There are hundreds of registered products enlisted in EPA (2013) ${ }^{[21] .}$

\section{Microbial pesticides \\ 2.1 Bacteria}

\subsubsection{Bacillus thuringiensis}

Beginning in the 1980 s and continuing to the present, a different molecular approach has been employed to develop market acceptance of biopesticides. Earlier, several efforts were aimed at establishing microbial insecticides, like $B t$, which has been used commercially over 40 years (Gelernter and Schwab 1993) ${ }^{[24]}$. Later, some Bacillus species such as Bacillus thuringi- ensis israelensis Bti and Bacillus sphaericus 2362 (Bs) were found particularly effective against mosquito (Revathi et al. 2013) ${ }^{[57]}$ and other dipteran larvae. $B t i$ was first discovered to have increased toxicity against mosquito larvae in 1975 (Goldberg and Margalit 1977) ${ }^{[28]}$.

Various bacterial species and subspecies, especially Bacillus, Pseudomonas, etc., have been established as biopesticides and are primar- ily used to control insect and plant diseases. Most salient among these are insecticides based on several subspecies of Bacillus thuringiensis Berliner. These include B. thuringiensis ssp. kurstaki and aizawai, with the highest activity against lepidopteran larval species; B. thuringi- ensis israelensis, with activity against mosquito larvae, black fly (simuliid), and fungus gnats; B. thuringiensis tenebrionis, with activity against coleopteran adults and larvae, most notably the Colorado potato beetle (Leptinotarsa decemlineata); and B. thuringiensis japonensis strain Buibui, with activity against soil-inhabiting beetles (Carlton 1993; Copping and Menn 2000) ${ }^{[9,15]}$. Bt produces crystalline proteins and kills few target insect pest species like lepidopteran species. The binding of the $B t$ crystalline proteins to insect gut receptor determines the target insect pest (Kumar 2012) ${ }^{[38]}$.

Toxicity of Bti and some other toxic strains is commonly imputed to the parasporal inclusion bodies ( $\delta$-endotoxins) which are produced during sporulation time. These endotoxins must be assimilated by the larvae to accomplish toxicity. $B t$ and their subspecies produce different insecticidal crystal proteins ( $\delta$-endotoxins), and their toxicity was determined (Chilcott et al. 1983) ${ }^{[14]}$. These toxins, when ingested by the larvae, can damage the gut tis- sues, leading to gut paralysis. After that, the infected larvae stop feeding and finally they die from the combined effects of starvation and mid- gut epithelium impairment (Betz et al. 2000) ${ }^{[7]}$.

Some other microbial pesticides act by out- competing insect pest organisms. Microbial pesticides need to be continuously supervised to ensure that they do not become capable of injuring nontarget organisms, including humans (Mazid et al. 2011) ${ }^{[44]}$. In previous studies, the microbial pesticide advance has resulted in a sig- nificant decrease of synthetic chemical insecti- cide usage (James 2009) ${ }^{[35]}$.

Gray et al. (2006) ${ }^{[29]}$ reported $B t$ toxins produced by plant growth-promoting rhizobacteria, which also develop bacteriocin compounds of insecti- cidal attributes. $B t$ is marketed worldwide for the control of different important plant pests, mainly caterpillars, mosquito larvae, and black flies. Commercial $B t$-based products include powders containing a combination of dried spores and crystal toxins. They are applied on leaves or other environments where the insect larvae feed. Toxin genes from $B t$ have been genetically engineered into several crops.

\section{Fungi}

\subsection{Metarihizium anisopliae}

M. anisopliae Sorokin var. anisopliae is an essential entomopathogenic fungus. It propa- gates worldwide in the soil, demonstrating a wide range of insect host species. This subspe- cies was first described in 1879 by Metschnikoff, under the term Entomophthora anisopliae, as a pathogen of the wheat cockchafer, and later it was termed M. anisopliae by Sorokin in 1883 (Tulloch 1976) ${ }^{[70]}$.

Several entomopathogenic fungi and their derivatives are also used as microbial pesticides. M. anisopliae are hyphomycete entomopathogenic fungi most widely used for insect pest control and are ubiquitous worldwide. This species comprises a huge number of different strains and isolates of various geographical origins and from different types of hosts (Roberts and St. Leger 2004) ${ }^{[59]}$.

Under natural conditions, Metarhizium are found in the soil, where the moist conditions per- mit filamentous growth and production of infec- tious spores, called conidia, which infect soil-dwelling insects upon contact. M. anisopliae has the potential to be used as a bio- control agent, particularly for malaria vector spe- cies, and is also a suitable candidate for further research and development Driver et al. (2000) ${ }^{[19]}$ reevaluated the taxonomy of the genus Metarhizium using sequence data from ITS and 28S rDNA D3 regions and also using RAPD patterns, revealing ten distinguishable clades. $M$. anisopliae var. anisopliae represents clade 9. These entomopathogenic fungi have been viewed as safe and regarded as an environmentally satisfactory alternative to synthetic chemical pesti- cides (Domsch et al. 1980) ${ }^{[18]}$. Recently, these entomopathogenic fungi have been registered as microbial agents and are also under commercial development for the biological control of several pests (Butt et al. 2001a, b) ${ }^{[8]}$.

M. anisopliae strains are obtained from different geographical localities (Fegan et al. 1993) [23], as sug- gested, among others, by extremely variable toxici- ties (Goettel and Jaronski 1997) ${ }^{[26]}$. M. anisopliae have been used on a large scale in countries like Brazil, where 100,000 ha of sugarcanes are treated every year (Faria and Magalhães 2001) ${ }^{[22]}$. They are released in the field after thorough assessment of strains. Consorting to Goettel et al. (2001) ${ }^{[27]}$ have reported that the growth and application of fungi as micro- bial agents for biocontrol of insect pest involve tests with mammalian models to evaluate possible human and animal health risks. 


\section{Virus}

\subsection{Baculovirus}

Baculoviruses are double-stranded DNA viruses present in arthropods, mainly insects. Baculoviruses are usually highly pathogenic and have been used efficaciously in their natural form as biocontrol agents against numerous serious insect pests (Moscardi 1999) ${ }^{[50]}$. Even so, the application of baculoviruses is still limited in the field of agricul- ture and horticulture where the thresholds for pest damage tend to be minimized. In Lepidoptera, i.e., the primary group where baculoviruses have been isolated, they only cause mortality in the larval stage (Cory 2000) ${ }^{[16]}$.

Baculoviruses need to be ingested by the lar- vae to initiate infection. After ingestion, they enter the insect's body through the midgut and from there they spread throughout the body, although in some insects, infection can be limited to the insect midgut or the fat body. Two groups of baculoviruses exist: the nucleopoly- hedroviruses (NPVs) and granuloviruses (GVs). In NPVs, occlusion bodies comprise numerous virus particles, but in GVs, occlusion bodies ordinarily contain just one virus particle. A common feature of baculoviruses is that they are occluded, i.e., the virus particles are embedded in a protein matrix. The presence of occlusion bodies plays an essential role in baculovirus biology as it allows the virus to survive outside the host (Cory 2000) ${ }^{[16]}$

Recently, it has been substantially demonstrated that baculoviruses are not infectious to vertebrates and plants. Also within the insects, their host range is restricted to the order from which they were iso- lated. Genetic engineering of baculoviruses has so far been restricted to isolates from Lepidoptera (Kolodny-Hirsch et al. 1997) ${ }^{[37]}$. Baculoviruses vary in the number of hosts that they can infect; some seem to be particular to one species and hence are very unlikely to be a hazard when genetically mod- ified, whereas others infect a range of hosts (Barber et al. 1993) ${ }^{[5]}$. The majority of new baculovirus recombi- nants now employ insect-selective toxins. Genetic modification has been mostly carried out on the alfalfa looper, Autographa califor- nica NPV (AcNPV)the virus for which most molecular information is available, including the complete DNA sequence, which permits precise insertion of foreign genes. Recently, the development of genetically modified baculovi- ruses has expanded to other strains of commer- cial or regional interest (Cory 2000) ${ }^{[16]}$.

Baculovirus-infected insect larvae have pri- marily initiated a cascade of molecular and cel- lular appendages finally the larva enters into the death and the development of huge amounts of polyhedral occlusion bodies comprising rodshaped virions (Miller 1997) ${ }^{[47]}$. Lately, a naturally occurring baculovirus (Agrotis ipsilon multiple nucleopolyhedrovirus, family Baculoviridae, AgipMNPV) was indicated to have hope as a microbial insecticide for controlling A. ipsilon in turf (Prater et al. 2006) ${ }^{[56]}$.

Numerous viral formulations are available pri- marily for the control of caterpillar pests. For instance, Certis has recently registered Madex ${ }^{\mathrm{TM}}$, an increased-potency codling moth granulosis virus $(\mathrm{GV})$ that also affects oriental fruit moth (OFM). Certis also deals Cyd-X ${ }^{\mathrm{TM}}$, which also contains the codling moth GV and which can be an efficient tool for codling moth management (Arthurs and Lacey 2004) ${ }^{[2]}$. Aside from Madex and Cyd-X, Certis markets Gemstar ${ }^{\mathrm{TM}}$, which contains Heliothis zea NPV, and Spod-X $\mathrm{X}^{\mathrm{TM}}$, which contains beet armyworm NPV. Gemstar is also registered for the control of lepidopteran pests, like the cotton bollworm and budworm, caterpillars that are mainly dangerous insect pests of corn, soybean, and other vegeta- bles. Furthermore, Certis has registered a celery looper (Syngrapha fal- cifera) NPV and an alfalfa looper (Autographa californica) NPV (EPA 2006) ${ }^{[21]}$.

\section{Nematodes}

\subsection{Steinernema (Rhabditida)}

One of the new hot products in biopesticide is nematodes. Pest nematodes can be supervised with cover crops, crop rotation, and internaliza- tion of organic material into the soil (McSorely 1999) ${ }^{[45]}$. In the early 1990s, various effective ento- mopathogenic nematodes from two genera, namely, Steinernema and Heterorhabditis (Nematoda: Rhabditida), were discovered and established as a biocontrol agent against insects (Copping and Menn 2000) ${ }^{[15]}$.

Insect-parasitic nematodes may encroach upon soil-dwelling stages of insects and kill them within $48 \mathrm{~h}$ through the expulsion of pathogenic bacteria. After the host dies, the infectious stages of the nematodes become adults and a modern generation of infective juveniles (IJs) develops. Entomopathogenic nematodes are com- monly available for plant protection from serious insect pests and diseases, and also there have been various efforts to biocontrol insect pest pop- ulations in the field by employing IJs via spray- ing. Nevertheless, little is known about the ability of indigenous nematodes to influence insect pest populations (Peters 1996) [53].

In nematodes, the parasitic cycle is initiated by the third-stage IJs. These nonfeeding juveniles infest suitable insect host and enter through the insect's natural body openings like the anus, mouth, and spiracles (Grewal et al. 1997) ${ }^{[30]}$. Once they have entered inside the host, nematodes infest the hemocoel and then release their symbi- otic bacteria into the intestine. After that, the bac- teria cause septicemia, killing the host within 24-48 h. The uptake of IJs is rapidly manipulating by the bacteria and decomposed the host tissues. Almost two to three generations of the nematodes are finished within the host cadaver (Pomar and Leutenegger 1968) ${ }^{[54]}$.

In previous research studies, it has been clearly indicated that entomopathogenic nema- todes can be effective biocontrol agents against some of the major insect pest families found in stored goods like Pyralidae (Shannag and Capinera 2000) ${ }^{[66]}$ and Curculionidae (Duncan and McCoy 1996) [20]. demonstrated the susceptibil- ity of insect pests found in stored products, including Ephestia kuehniella Zeller and Tenebrio molitor L., to an increased concentra- tion of nematodes. Georgis (1990) ${ }^{[25]}$ had also advo- cated a field concentration of $>2.5$ billion nematodes/ha against some of the major insect pests of row crops, but concentrations few times higher (7-15 billion/ha) are demanded to accom- plish the control of pest population (Loya and Hower 2002) ${ }^{[41]}$.

\section{Protozoa}

\subsection{Nosema}

In previous studies, protozoan diseases of insects are ubiquitous in nature and constitute an essential regulatory role in insect populations (Maddox 1987) ${ }^{[42]}$. Microsporidia, such as Nosema spp., are generally host specific and slow acting, most frequently producing chronic infections. The biological activities of most entomopathogenic protozoa are complex. They grow only in living hosts and some spe- cies necessitate an intermediate host. Microsporidia species are among the most commonly observed, and their main benefits are persistence and recycling in host popula- tions and their debilitating effect on reproduc- tion and overall fitness of target insects. As inundatively utilized microbial control 
agents, some species have been moderately successful (Solter and Becnel 2000) ${ }^{[68]}$.

Some protozoan species are pathogenic like Nosema locustae for grasshoppers, which is the only species that has been registered and estab- lished commercially (Henry and Oma $1981)^{[32]} . N$. bombycis, the first reported microsporidium, is a pathogen of silkworm pébrine, which persisted in Europe, North America, and Asia during the mid-nineteenth century (Becnel and Andreadis 1999) ${ }^{[6]}$. Pébrine is still an epidemic and causes heavy economic losses in silk-producing countries such as China (Cai et al. 2012).

Almost 1,000 protozoan species, mainly micro- sporidia, attack invertebrates, including numerous insect species like grasshoppers and heliothine moths. Virtually renowned insect-pathogenic pro- tozoan species are Nosema spp. and Vairimorpha necatrix. Protozoans produce spores, which are the infectious phase in several susceptible insects. Nosema spp. spores are assimilated by the host and develop in the midgut. Germinating spores are released from the sporoplasm and invade host tar- get cells, inducing massive infection and demol- ishing organs and tissues. Sporulation process begins again from the infected tissues and, upon expulsion and ingestion by a susceptible host, induces an epizootic infection. Naturally, parasit- oids and insect predators commonly act as vectors distributing the disease.

\section{Botanicals}

Since ancient times, natural compounds from plants were used, more or less efficaciously to give security from insect pests. In the nineteenth century, these compounds became scientifically established and widely utilized in the earlier period of the twentieth century (Morgan 2004) ${ }^{[49]}$. Plants and some insects have coexisted on the earth for almost three and a half million years, which has allowed lots of time for both to develop offensive and defensive strategies. Plants have developed many strategies to assist themselves from being assaulted by predators. An example of such plant strategy is developing compounds that are highly toxic to insects (Nisha et al. 2012) ${ }^{[52]}$.

\subsection{Neem}

In Asia, neem has an extensive history of use mainly against household and storage pests and, to some extent, against insect pests of crops. Nevertheless, a breakthrough in the insecticidal application of neem was attained by Pradhan et al. (1962) who successfully protected the crops from insects by applying them with low concen- tration of $0.1 \%$ neem seed kernel suspension during a locust invasion. The Indian neem tree (Azadirachta indica) is one of the most important limonoid-producing plants from the Meliaceae family. Several components of its leaves and seeds show marked insect control potential, and due to their relative selectivity, neem products can be recommended for many programs on crop pest management (Schmutterer 1990) ${ }^{[60]}$. Neem product activity has been assessed against 450-500 insect pest species in different countries around the world, and from that, 413 insect pest species are reportedly susceptible at various concentrations (Schmutterer and Singh 1995) ${ }^{[61]}$.

In India alone, neem activity has been assessed against 103 species of insect pests, 12 nematodes, and several pathogenic fungi (Arora and Dhaliwal 1994) ${ }^{[1]}$. Some recent reviews on the potential of neem in pest manage- ment include those of Singh and Raheja (1996) ${ }^{[67]}$, Naqvi (1996) ${ }^{[51]}$, and Dhaliwal and Arora (2001) [17]. Most works have focused on azadirachtin richly from neem seed extracts which act as both strong antifeed- ants and insect growth regulators. Azadirachtin affects the physiological activities of insects (Mordue (Luntz) and Blackwell 1993) ${ }^{[48]}$ and does not affect other biocontrol agents. Further, neem products are biodegradable and nontoxic to non- target organisms (SenthilNathan 2013).

In several Asian countries, numerous studies have measured neem activity alone or in combi- nation with established insecticides and other biocontrol agents of damaging insect pests in agricultural crop system. In Indian field trials carried out, neem treatments were determined to be effective against some insect species like green leafhopper, yellow stem borer, rice gall midge, rice leaffolder, and grass- hopper (SenthilNathan et al. 2009).

\subsection{Melia azedarach}

The promotion of botanicals as eco-friendly pes- ticides, microbial sprays, and insect growth regu- lators has been a major concern amid the presence of other control measures like beneficial insects, all of which demand an integration of supervised insect pest control (Ascher et al. 1995) ${ }^{\text {[3] }}$. Plantbased insecticides are developed naturally from plant chemicals extracted for use against serious insect pests. As a result of concerns about the ecological continuity of synthetic pesticides and their potential toxicity to humans, nontarget ben- eficial insects, and some domestic animals, there is a regenerated interest in natural products to control insect pests. From this conclusion, the development of biopesticides seems to be a logi- cal choice for further investigation. Meliaceae and Rutaceae species have received much atten- tion due to the fact that they are a rich source of triterpenes known as limonoids (Connolly 1983).

The Meliaceae plant family is known to hold an assortment of compounds with insecticidal, antifeedant, growth-regulating, insect-deforming, and growth-modifying properties (Champagne et al. 1989; Schmutterer 1990; Mordue (Luntz) and Blackwell 1993; Senthil-Nathan and Kalaivani 2005) [11, 60, 48, 64]. M. azedarach, otherwise known as chinaberry or Persian lilac tree, is a deciduous tree that origi- nates from northwestern India, and it has been recognized for its insecticidal properties, which are still to be entirely analyzed. This tree grows in the tropical and subtropical parts of Asia, but nowadays it is also cultivated in other warm places of the world because of its considerable climatic tolerance. The leaves of $M$. azedarach are used for their insecticidal activity, whereas the fruit extracts of $M$. azedarach produce a vari- ety of effects in insects, such as growth retarda- tion, reduced fecundity, molting disorders, and behavior changes (Ascher et al. 1995) ${ }^{[3]}$. The antifeedant and insect growth-regulating effects of $M$. azedarach extracts are known for many insects (Carpinella et al. 2003, Senthil-Nathan and Sehoon 2006) [62, ${ }^{65]}$, the latter effect being the most essential physiological effect of M. azedarach on insects (Ascher et al. 1995) ${ }^{[3]}$.

As previously mentioned, the Meliaceae plant family has been known as a potential source for insecticide properties. Also, several extracts from neem and other plant seeds and leaves have excel- lent insecticidal properties against vectors and are at the same time very eco-friendly (Schmutterer 1990) ${ }^{[60] .}$ The effi- caciousness of these neem products on mosqui- toes was also demonstrated (Chavan 1984; Schmutterer 1990; Su and Mulla 1999; Senthil-Nathan et al. 2005d) ${ }^{[13,60,64]}$.

Without a doubt, plant-derived toxicants are a valuable source of potential insecticides. Plants and other natural insecticides may play a vital role in mosquito control programs as well as 
in other major insect control programs (Mordue (Luntz) and Blackwell 1993) ${ }^{[48]}$.

\section{Biochemicals}

\subsection{Pheromones}

Insects produce chemicals called pheromones to stimulate a certain behavioral reaction from other individuals. These pheromones have numerous effects and are named according to their evoked response, for example, sex pheromones, aggrega- tion pheromones, alarm pheromones, etc. A few pheromones function as sex attractants, permit- ting individuals to detect and locate mates, whereas others induce trail following, oviposi- tion, and aggregation in other congeners. Pheromones have become essential tools for monitoring and controlling agricultural pest pop-ulations, and as such, a huge collection of over 1,600 pheromones and sex attractants has been reported (Witzgall et al. 2004).

In the past decades, there has been a significant volume of literature on insect pheromones and new opportunities have arisen to explore the use of semiochemicals in managing insect pest prob- lems. Insect control by pheromones alone has pre- cincts, but they can be applied in integrated control in combination with other practices (Howse et al. 1998; Reddy and Guerrero 2004) ${ }^{[34,57]}$. Plant volatiles are recognized as an integral part of the pheromone system of various Coleopteran species studied so far. How the combinations of pheromones and plant volatiles are incorporated into the insects' olfactory systems so that they can discriminate pheromone molecules alone and pheromone plus odor plume strands and react behaviorally to these signals is a question of increasing importance (Baker and Heath 2004) ${ }^{[4]}$.

Recently, the pest management system has undergone an intentional shift from calendar- based, broad-spectrum insecticide applications to more holistic, integrated, and highefficacy approaches. Furthermore, environmental conservation, food safety, and resistance management are a few of the key components guiding current pest management policies in commercial agricul- ture (Witzgall et al. 2010) ${ }^{[72]}$.

Kogan and Jepson (2007) ${ }^{[36]}$ had reported that meeting the necessities of the quickly expanding global population while incorporating sustain- ability and ecological stewardship is a major challenge facing modern agriculture. In agricul- tural fields, the application of pheromones and/or allelochemicals as behavioral manipulation tools can replace or complement existing pest manage- ment programs (Witzgall et al. 2008) [71], resulting in a decreased rate of broad-spectrum use.Nowadays, pheromones and other semio- chemicals are applied to monitor and control pests in millions of hectares. There are several advantages of utilizing pheromones for monitor- ing pests, including lower costs, specificity, ease of use, and high sensitivity (Laurent and Frérot 2007; Witzgall et al. 2010) ${ }^{[39,72]}$. Insect pest monitoring by using pheromone lures can profit management conclusions such as insecticide application timing (Leskey et al. 2012; Peng et al. 2012) ${ }^{[40]}$.

Pheromones produced by insects are highly species specific. Virgin female insects are devel- oping sex pheromones when expecting for a mate and males along the concentration slope for the female producer. Aggregation pheromones are released by insects such as wood-invading bee- tles to show to others the presence of a good food source (Copping and Menn 2000) ${ }^{[15]}$.

Some of the alarm pheromones are developed by insects that are beneath approach from a pred- ator and this contributes to a movement of the insect pest aside from the production source and, therefore it becomes dangerous. Plants and its derived attractants are also known that interact with the insects to a valuable food source and, while combine with insect-derived attractants will be developed a potent attraction to some insect pests (Copping and Menn 2000) ${ }^{[15]}$.

In previous studies, Mayer and McLaughlin (1991) [43] proposed that all insects produce approxi- mate form of pheromone and companies subsist that synthesize a pheromone for any customer. Recently, 30 mating-disruption pheromone- based products are registered by the US EPA as biocontrol agents of lepidopteran pest species that can cause agricultural damage (Copping and Menn 2000) ${ }^{[15]}$.

\section{Conclusion}

The utilization of natural products with commercial value is directly manifested by the numerous compounds present in the market and that have remained there in many cases after many years. These values of natural products are considered as a source of new mechanisms and their consequent incorporation into high-output screens is hard to evaluate. Recently, several works have been exercised and extend to be undertaken to enhance the shelf life, immediate death, the biological scheme, efficient in the field and dependability, and the effect of cost of living systems and there have been some notable successes in situations where some disruption to the crop is acceptable.

\section{References}

1. Arora R, Dhaliwal GS. Botanical pesticides in insect pest management. In: Dhaliwal GS, Kansal BD (eds) Management of agricultural pollution in India. Commonwealth Publications, New Delhi, 1994, 213-245.

2. Arthurs SP, Lacey LA. Field evaluation of commercial formulations of the codling moth granulovirus: persistence of activity and success of seasonal applications against natural infestations of codling moth in Pacific Northwest apple orchards. Biol Control. 2004; 31:388-397.

3. Ascher KRS, Schmutterer H, Zebitz CPW, Naqvi SNH. The Persian lilac or chinaberry tree: Melia aze-darach $\mathrm{L}$. In: Schmutterer H (ed) The neem tree: source of unique natural products for integrated pest management, medicine, industry and other purposes. $\mathrm{VCH}$, Weinheim, 1995, 605-642.

4. Baker TC, Heath JJ. Pheromones-function and use in insect control. In: Gilbert LI, Iatro K, Gill SS (eds) Molecular insect science. Elsevier, Amsterdam, 2004, 407-460.

5. Barber KN, Kaupp WJ, Holmes SB. Specificity testing of the nuclear polyhedrosis virus of the gypsy moth, Lymantria dispar (L.) (Lepidoptera: Lymantriidae). Can Entomol. 1993; 125:1055-1066.

6. Becnel JJ, Andreadis TG. Microsporidia in insects. In: Wittner M, Weiss LM (eds) The Microsporidia and Microsporidiosis. ASM Press, Washington, DC, 1999, 447-501.

7. Betz FS, Hammond BG, Fuchs RL. Safety and advantages of Bacillus thuringiensis-protected plants to control insect pests. Regul Toxicol Pharmacol. 2000; 32:156-173.

8. Butt TM, Jackson CW, Magan N. Fungi as bio- control agents: progress, problems and potential. $\mathrm{CAB}$ International, Wallingford, 2001a.

9. Carlton BC. Genetics of Bt insecticidal crystal pro- teins and strategies for the construction of improved strains. In: Duke SO, Menn JJ, Plimmer JR (eds), Pest control with 
enhanced environmental safety. ACS symposium series 524, American Chemical Society, Washington, DC. 1993, 326-337.

10. Carpinella MC, Defago MT, Valladares G, Palacios SM. Antifeedant and insecticide properties of a limonoid from Melia azedarach (Meliaceae) with potential use for pest management. J Agric Food Chem. 2003; 15:369-374.

11. Champagne DE, Isman MB, Towers GHN. Insecticidal activity of phytochemicals and extracts of the Meliaceae. In: Arnason JT, Philogene BJR, Morand P (eds) Insecticides of plant origin. American Chemical Society symposium series. 1989; 387:95-109.

12. Chandrasekaran R, Revathi K, Nisha S, Kirubakaran SA, Sathish-Narayanan S, Senthil-Nathan S. Physiological effect of chitinase purified from Bacillus subtilis against the tobacco cutworm Spodoptera litura Fab. Pestic Biochem Physiol. 2012; 104:65-71.

13. Chavan SR. Chemistry of alkanes separated from leaves of Azadirachta indica and their larvicidal/insec- ticidal activity against mosquitoes. In: Schmutterer $\mathrm{H}$, Ascher KRS (eds) Natural pesticides from the neem tree and other tropical plant, proceedings of the 2nd international neem conference, Rauischholzhausen, Federal Republic of Germany, 1983, 1984, 59-66.

14. Chilcott CN, Kalmakoff J, Pillai JS. Characterization of proteolytic activity associated with Bacillus thuringiensis var. israelensis crystals. FEMS Microbiol Lett. 1983; 18:37-41.

15. Copping LG, Menn JJ. Biopesticides: a review of their action, applications and efficacy. Pest Manag Sci. 2000; 56:651-676.

16. Cory JS. Assessing the risks of releasing geneti- cally modified virus insecticides: progress to date. Crop Prot. 2000; 19:779-785.

17. Dhaliwal GS, Arora R. Role of phytochemicals in integrated pest management. In: Koul O, Dhaliwal GS (eds) Phytochemical biopesticides. Harwood Academic Publishers, Amsterdam, 2001, 97-117.

18. Domsch KH, Gams W, Anderson TH. Compendium of soil fungi. Academic, London, 1980, 413-415.

19. Driver F, Milner RJ, Trueman JWH. A taxonomic revision of Metarhizium based on a phylogenetic analysis of rDNA sequence data. Mycol Res. 2000; 104:134150.

20. Duncan LW, McCoy CW. Vertical distribution in soil, persistence, and efficacy against citrus root weevil (Coleoptera: Curculionidae) of two species of entomogenous nematodes (Rhabditida: Steinernematidae; Heterorhabditidae). Environ Entomol. 1996; 25:174-178.

21. EPA (Environmental Protection Agency) New biopesticide active ingredients. 2006. www.epa.gov/pesti- cides/biopesticides/product lists/. Accessed 23 July 2013.

22. Faria MR, Magalhães BP. O uso de fungos entomopatogênicos no Brasil. Biotecnol Cienc Desenvolvimento. 2001; 22:18-21.

23. Fegan M, Manners JM, Maclean DJ, Irwin JAG, Samuels KDZ, Holdom DG et al. Random amplified polymorphic DNA markers reveal a high degree of genetic diversity in the entomopathogenic fungus Metarhizium anisopliae var. anisopliae. Microbiology. 1993; 139:2075-2081.

24. Gelernter W, Schwab GE. Transgenic bacteria, viruses, algae and other microorganisms as Bacillus thuringiensis toxin delivery systems. In: Entwistle PF, Cory JS, Bailey MJ, Higgs S (eds) Bacillus thuringi- ensis, an environmental biopesticide: theory and prac- tice. Wiley, Chichester, 1993, 89-124.

25. Georgis R. Formulation and application technol- ogy. In: Gaugler R, Kaya HK (eds) Entomopathogenic nematodes in biological control. CRC Press, Boca Raton, 1990, 173191.

26. Goettel MS, Jaronski ST. Safety and registration of microbial agents for control of grasshoppers and locusts. In: Goettel MS, Johnson DL (eds) Microbial control of grasshoppers and locusts, Memoirs of the Entomological Society of Canada., 1997; 171:83-99.

27. Goettel MS, Hajek AE, Siegel JP, Evans HC. Safety of fungal biocontrol agents. In: Butt TM, Jackson C, Magan $\mathrm{N}$ (eds) Fungi as biocontrol agents: progress, problems and potential. CAB International, Wallingford, 2001, 347-375.

28. Goldberg LH, Margalit J. A bacterial spore demonstrating rapid larvicidal activity against Anopheles sergentii, Uranotaenia unguiculata, Culex univittatus, Aedes aegypti and Culex pipiens. Mosq News. 1977; 37:355358.

29. Gray EJ, Lee KD, Souleimanov AM, Di Falco MR, Zhou X, Ly A et al. A novel bacteriocin, thuricin 17, produced by plant growth promoting rhizobacteria strain Bacillus thuringiensis NEB17: isolation and classification. J Appl Microbiol. 2006; 100:545-554.

30. Grewal PS, Lewis EE, Gaugler R. Response of infective stage parasites (Nematoda: Steinernematidae) to volatile cues from infected hosts. J Chem Ecol. 1997; 23:503-515

31. Grewal PS, Ehlers RU, Shapiro-Ilan DI. Nematodes as biocontrol agents. CABI Publishing, Wallingford, 2005, 505 .

32. Henry JE, Oma EA. Pest control by Nosema locus- tae, a pathogen of grasshoppers and crickets. In: Burges HD (ed) Microbial control of pests and plant diseases. Academic, London, 1981, 573-586.

33. Hom A. Microbials, IPM and the consumer. IPM Pract 1996; 18:1-11.

34. Howse P, Stevens I, Jones O. Insect pheromones and their use in pest management. Chapman and Hill, London, 1998, 639.

35. James C. Global status of commercialized biotech/ GM crops. ISAAA Brief No. 41, I. ISAAA, Ithaca, 2009.

36. Kogan M, Jepson P. Ecology, sustainable develop- ment and IPM: the human factor. In: Kogan M, Jepson P (eds) Perspectives in ecological theory and inte- grated pest management. Cambridge University Press, Cambridge, UK, 2007, 1-44.

37. Kolodny-Hirsch DM, Sitchawat T, Jansiri T, Chenrchaivachirakul A, Ketunuti U. Field eval- uation of a commercial formulation of the Spodoptera exigua (Lepidoptera: Noctuidae) nuclear polyhedrosis virus for control of beet armyworm on vegetable crops in Thailand. Biocontrol Sci Tech. 1997; 7:475-488.

38. Kumar S. Biopesticides: a need for food and environmental safety. J Biofertil Biopestic. 2012; 3:4.

39. Laurent P, Frérot B. Monitoring of European corn borer with pheromone-baited traps: review of trapping system basics and remaining problems. J Econ Entomol. 2007; 100:1797-1807.

40. Leskey TC, Wright SE, Short BD, Khrimian A. Development of behaviorally-based monitoring tools for the brown marmorated stink bug (Heteroptera: Pentatomidae) in commercial tree fruit orchards. J Entomol Sci. 2012; 47:76-85. 
41. Loya LJ, Hower AA Jr. Population dynamics, persistence, and efficacy of the entomopathogenic nematode Heterorhabditis bacteriophora (Oswego strain) in association with the clover root curculio (Coleoptera: Curculionidae) in Pennsylvania. Environ Entomol. 2002; 31:1240-1250.

42. Maddox JV. Protozoan diseases. In: Fuxa JR, Tanada Y (eds) Epizootiology of insect diseases. Wiley, New York, 1987, 417-452.

43. Mayer MS, McLaughlin JR. Handbook of insect pheromones and sex attractants. CRC Press, Boca Raton, 1991.

44. Mazid S, Kalida JC, Rajkhowa RC. A review on the use of biopesticides in insect pest management. Int J Sci Adv Technol. 2011; 1:169-178.

45. McSorely R. Non-chemical management of plantparasitic nematodes. IPM Pract. 1999; 21:1-7.

46. Menn JJ, Hall FR. Biopesticides: present status and future prospects. In: Hall FR, Menn JJ (eds) Biopesticides use and delivery. Humana Press, Totowa, 1999, 1-10.

47. Miller LK. The Baculovirus. Plenum Press, New York, 1997, 7-32.

48. Mordue (Luntz) AJ, Blackwell A. Azadirachtin: an update. J Insect Physiol. 1993; 39:903-924.

49. Morgan ED. The place of neem among modern natural pesticides. In: Koul O, Wahab S (eds) Neem: today and in the New Millennium. Kluwer Academic Publishers, Dordrecht, Holland, 2004, 21-32.

50. Moscardi F. Assessment of the application of baculoviruses for control of Lepidoptera. Annu Rev Entomol. 1999; 44:257-289.

51. Naqvi SNH. Prospects and development of a neem based pesticide in Pakistan. In: Proceedings of the 16th Congress of Zoology, Islamabad, 1996, 325-338.

52. Nisha S, Revathi K, Chandrasekaran R, Kirubakaran SA, Sathish-Narayanan S, Stout MJ et al. Effect of plant compounds on induced activi- ties of defense-related enzymes and pathogenesis related protein in bacterial blight disease susceptible rice plant. Physiol Mol Plant Pathol. 2012; 80:1-9.

53. Peters A. The natural host range of Steinernema and Heterorhabditis spp. and their impact on insect populations. Biocontrol Sci Technol. 1996; 6:389-402.

54. Pomar GO Jr, Leutenegger R. Anatomy of the effective and normal third stage juveniles of Steinernema carpocapsae Weiser (Steinernematidae: Nematoda). J Parasitol. 1968; 54:340-350.

55. Pradhan S, Jotwani MG, Rai BK. The neem seed deterrent to locust. Indian Farm. 1962; 12:7-11.

56. Prater CA, Redmond C, Barney W, Bonning BC, Potter DA. Microbial control of black cutworm (Lepidoptera: Noctuidae) in turfgrass using Agrotis ipsilon multiple nucleopolyhedrovirus. J Econ Entomol. 2006; 99:11291137.

57. Reddy GVP, Guerrero A. Interactions of insect pheromones and plant semiochemicals. Trends Plant Sci 2004; 9:253-261.

58. Revathi K, Chandrasekaran R, Thanigaivel A, Kirubakaran SA, Sathish-Narayanan S, Senthil-Nathan S. Effects of Bacillus subtilis metabolites on larval Aedes aegypti L. Pestic Biochem Physiol. 2013; 107:369-376.

59. Roberts DW, St Leger RJ. Metarhizium spp., cosmopolitan insect-pathogenic fungi: mycological aspects. Adv Appl Microbiol. 2004; 54:1-70.
60. Schmutterer H. Properties and potential of natural pesticides from the neem tree, Azadirachta indica. Annu Rev Entomol. 1990; 35:271-297.

61. Schmutterer H, Singh RP. List of insect pests susceptible to neem products. In: Schmutterer H (ed) The neem tree: source of unique natural products for integrated pest management, medicine, industry and other purposes. VCH, Weinheim, 1995, 325-326.

62. Senthil-Nathan S, Sehoon K. Effects of Melia azedarach L. extract on the teak defoliator Hyblaea puera Cramer (Lepidoptera: Hyblaeidae). Crop Prot. 2006; 25:287-291.

63. Senthil-Nathan S, Chung PG, Murugan K. Effect of botanical insecticides and bacterial toxins on the gut enzyme of the rice leaffolder Cnaphalocrocis medina- lis. Phytoparasitica. 2004; 32:433-443.

64. Senthil-Nathan S, Kalaivani K, Murugan K. Effects of neem limonoids on the malaria vector Anopheles stephensi Liston (Diptera: Culicidae). Acta Trop. 2005d; 96:47-55.

65. Senthil-Nathan S, Kalaivani K, Murugan K. Behavioural responses and changes in biology of rice leaf folder following treatment with a combination of bacterial toxins and botanical insecticides. Chemosphere. 2006; 64:1650-1658.

66. Shannag HK, Capinera JL. Interference of Steinernema carpocapsae (Nematoda: Steinernematidae) with Cardiochiles diaphaniae (Hymenoptera: Braconidae), a parasitoid of melonworm and pickleworm (Lepidoptera: Pyralidae). Environ Entomol, 2000; 29:612-617.

67. Singh RP, Raheja AK. Strategies in management of insect pests with neem (Azadirachta indica A. Juss). In: Singh RP, Chari MS, Raheja AK, Kraus W (eds) Neem and environment, Oxford \& IBH Publishing Co. Pvt. Ltd., New Delhi, 1996; 1:103-120.

68. Solter LF, Becnel JJ. Entomopathogenic microspo- rida. In: Lacey LA, Kaya HK (eds) Field manual of techniques in invertebrate pathology: application and evaluation of pathogens for control of insects and other invertebrate pests. Kluwer Academic, Dordrecht, 2000, 231-254.

69. Su T, Mulla MS. Oviposition bioassay responses of Culex tarsalis and Culex quinquefasciatus to neem products containing azadirachtin. Entomol Exp Appl 1999; 91:337-345.

70. Tulloch M. The genus Metarhizium. Trans Br Mycol Soc. 1976; 66:407-41.1

71. Witzgall P, Stelinski L, Gut L, Thomson D. Codling moth management and chemical ecology. Annu Rev Entomol. 2008; 53:503-522.

72. Witzgall P, Kirsch P, Cork A. Sex pheromones and their impact on pest management. J Chem Ecol. 2010; 36:80100. 